RASĀYAN J. Chem.

Vol. 13 | No. 1 |322 - 326| January - March | 2020 ISSN: 0974-1496 | e-ISSN: 0976-0083 | CODEN: RJCABP http://www.rasayanjournal.com http://www.rasayanjournal.co.in

\title{
TWO FLAVANONES FROM FINGER-ROOT (Curcuma rotunda) AND ITS ANTIBACTERIAL ACTIVITIES
}

\author{
Purwantiningsih $^{1}{ }^{, *}$, N. Jannah ${ }^{1}$ and D. U. C. Rahayu ${ }^{2}$ \\ ${ }^{1}$ Department of Chemistry, Institut Pertanian Bogor, Bogor, West Java, 16680, Indonesia \\ ${ }^{2}$ Department of Chemistry, Universitas Indonesia, Depok, West Java, 16424, Indonesia \\ *E-mail: purwantiningsih@apps.ipb.ac.id
}

\begin{abstract}
Finger-root (Curcuma rotunda) belongs to Zingiberaceae family, commonly used as a medicinal plant but has not been widely reported for its secondary metabolites and bioactivities. This study aims to isolate and characterize secondary metabolites contained in the semi-polar extract of $C$. rotunda rhizomes and evaluate its antibacterial activities. Simplicia of $C$. rotunda rhizomes was macerated using acetone, fractionated using vacuum liquid chromatography followed by radial chromatography, and purified using preparative thin layer chromatography to yield two isolated compounds. Based on FTIR and NMR spectroscopic data, two isolated compounds were elucidated as flavanone derivatives i.e. pinocembrin (1) and pinostrobin (2). Nevertheless, both of two isolated compounds did not show antibacterial activities toward Staphylococcus aureus and Pseudomonas $\mathrm{sp}$
\end{abstract}

Keywords: Antibacterial, Curcuma rotunda, Finger-root, Flavanone, Pinocembrin, Pinostrobin

(C) RASĀYAN. All rights reserved

\section{INTRODUCTION}

The resistance of antibiotics has become a serious and global concern in developed and developing countries since it is causing high mortality in the last years. ${ }^{1}$ The emergence of bacterial strains that exhibit resistance to various antibiotics including multi-drug and inappropriate antibiotic usage is becoming the most significant factor of treatment failure. ${ }^{2}$ Antibiotic resistance impacts the effective action of antibiotics resulting in prolonged illness and increased mortality. ${ }^{3}$ Therefore, alternative therapeutic agents from plants should be explored to manage these problems.

As part of our continuing efforts to discover responsible secondary metabolites from Curcuma genus plants in exhibiting some pharmacological activities ${ }^{4-9}$, we found that extract from Curcuma rotunda rhizomes displayed antibacterial activities toward foodborne pathogenic bacteria, cariogenic bacteria, and acne-causing bacteria. ${ }^{10}$ C. rotunda (Zingiberaceae), also known as "temu kunci" in Indonesia or fingerroot, is a famous traditional medicinal plant used in Indonesia to treat various ailments. ${ }^{11}$ According to phytochemical studies, the rhizomes of $C$. rotunda are a rich natural source of flavonoids, which have demonstrated wide-range of biological activities such as antioxidant, anticancer antibacterial, antiviral, anti-inflammatory ${ }^{10,12}$, anti-periodontal, anti-aging, antiulcer, anti-obesity, anti-hyperpigmentation ${ }^{10}$, antihypertensive $^{13}$, anti-platelet aggregation ${ }^{14}$, anti-autoimmune ${ }^{15}$, antidepressant ${ }^{16}$, anti-Alzheimer' ${ }^{17}$, anti-diabetic $^{12,18}$, neuro- and cardioprotective properties ${ }^{12,19}$. However, the secondary metabolites having antibacterial activity in the rhizomes of $C$. rotunda have not yet been explored in detail. Therefore, the isolation of two flavanones (1-2) from $C$. rotunda rhizomes and their antibacterial activities toward Staphylococcus aureus and Pseudomonas sp are described in this paper.

\section{EXPERIMENTAL}

Material and Methods

The dried powdered of C. rotunda rhizomes were purchased and identified in January 2017 from Pusat Studi Biofarmaka Tropika (Trop BRC) LPPM-IPB, West Java, Indonesia. FTIR spectra were acquired

Rasayan J. Chem., 13(1), 322-326(2020)

http://dx.doi.org/10.31788/RJC.2020.1315484

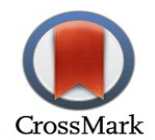


RASĀYAN J. Chem.

Vol. 13 | No. 1 |322 - 326| January - March | 2020

with Bruker Tensor 37 FTIR spectrometer. NMR spectra were performed on Agilent 500 instrument operating at 500 and $125 \mathrm{MHz}$ for ${ }^{1} \mathrm{H}$ and ${ }^{13} \mathrm{C}$, respectively. The melting point was measured using Mel Temp Model 1202D Barnstead ${ }^{\circledR}$ apparatus. Vacuum Liquid Chromatography (VLC) was carried out using Si $60 \mathrm{G}$ and Si 60 0.2-0.5 mm (Merck) for column packed and sample adsorbed, respectively. Radial Chromatography (RC) and Preparative Thin Layer Chromatography (P-TLC) were accomplished with Si $60 \mathrm{PF}_{254}$ containing gypsum and $\mathrm{Si} 60 \mathrm{GF}_{254}$ (Merck), respectively. Pre-coated silica gel plates (Merck, Si $60 \mathrm{GF}_{254}, 0.25 \mathrm{~mm}$ thickness) were used for TLC. TLC and P-TLC spots were identified under UV light (254 and $366 \mathrm{~nm}$ ) or by heating after spraying with $\mathrm{Ce}\left(\mathrm{SO}_{4}\right)_{2} .4 \mathrm{H}_{2} \mathrm{O} 1.5 \%$ in $\mathrm{H}_{2} \mathrm{SO}_{4} 2 \mathrm{~N}$.

\section{General Procedure}

Sample $(1.24 \mathrm{~kg})$ were macerated three times in acetone and filtered. The filtrate then was concentrated using rotavapor to obtain crude extract $(161 \mathrm{~g})$. The crude extract $(30 \mathrm{~g})$ was fractionated via VLC using an $n$-hexane-EtOAc gradient (from 9:1 to 1:1, v/v) to yield eight major fractions (A-H). Fraction C (11.9 g) was solvent partitioned with acetone to give acetone-soluble fraction $(1.75 \mathrm{~g})$. The acetone-soluble fraction $(1.22 \mathrm{~g})$ was further isolated via RC using $n$-hexane-EtOAc $(7: 3, \mathrm{v} / \mathrm{v})$ to afford eight fractions (C1-C8). Fraction C2 $(240 \mathrm{mg})$ then was subjected to repeat radial chromatography using the same solvent to yield nine sub-fractions (C21-C29). Sub-fraction C23 $(59.6 \mathrm{mg})$ was purified using preparative TLC ( $n$-hexane-EtOAc $=8.5: 1: 5, \mathrm{v} / \mathrm{v})$ to furnish pinocembrin $(21.1 \mathrm{mg}, 1.7 \%$ yield $)$ as compound 1. Fraction C5 (243.6 mg) was re-separated by radial chromatography using an $n$-hexane-EtOAc $(7: 3, \mathrm{v} / \mathrm{v})$ to yield eight sub-fractions (C51-C58). Fraction C4 (208.5 mg) and sub-fraction C54 (57.7 mg) then were consolidated and further purified via radial chromatography followed by preparative TLC using the same solvent to afford pinostrobin $(2,11.1 \mathrm{mg}, 0.9 \%$ yield). Antibacterial activities of all isolated compounds were performed using disc-diffusion method by measuring the diameter of a clear zone formed in millimeters ${ }^{20}$ with two bacteria, including $S$. aureus and Pseudomonas sp., purchased from Department of Biochemistry IPB. Chloramphenicol and DMSO were selected as a positive and negative control, respectively. Duplicates were maintained and the experiment was repeated twice.

\section{Pinocembrin (1)}

$\mathrm{C}_{15} \mathrm{H}_{12} \mathrm{O}_{4}$; yellow powder; mp. $189-190^{\circ} \mathrm{C}$; Rf: 0.12 in n-hexane-EtOAc $(9: 1, \mathrm{v} / \mathrm{v}), 0.46$ in n-hexane$\mathrm{CH}_{2} \mathrm{Cl}_{2}(1: 1, \mathrm{v} / \mathrm{v}), 0.81$ in $\mathrm{CH}_{2} \mathrm{Cl}_{2}$-EtOAc $(9: 1, \mathrm{v} / \mathrm{v})$; FTIR $(\mathrm{KBr}) v_{\max }: 3434,2962,1631,1604,1488$, $1302,1261,1168,861,825 \mathrm{~cm}^{-1}$; ${ }^{1} \mathrm{H}$ NMR $(500 \mathrm{MHz})$ and ${ }^{13} \mathrm{C}$ NMR $(125 \mathrm{MHz})$ in $\mathrm{CDCl}_{3}$ spectroscopic data, see Table 1 .

\section{Pinostrobin (2)}

$\mathrm{C}_{16} \mathrm{H}_{14} \mathrm{O}_{4}$; colorless-white powder; mp. $99-101^{\circ} \mathrm{C}$; Rf: 0.28 in n-hexane-EtOAc $(9: 1, \mathrm{v} / \mathrm{v}), 0.83$ in $\mathrm{n}$ hexane- $\mathrm{CH}_{2} \mathrm{Cl}_{2}(1: 1, \mathrm{v} / \mathrm{v}), 0.95$ in $\mathrm{CH}_{2} \mathrm{Cl}_{2}$-EtOAc $(9: 1, \mathrm{v} / \mathrm{v})$; FTIR $(\mathrm{KBr}) v_{\text {max }}: 3449,3060,2971-2910$, 1647, 1621-1580, 1497-1444, 1383, $840 \mathrm{~cm}^{-1}$; ${ }^{1} \mathrm{H}$ NMR (500 MHz) and ${ }^{13} \mathrm{C} \mathrm{NMR}(125 \mathrm{MHz})$ in $\mathrm{CDCl}_{3}$ spectroscopic data, see Table-1.

\section{RESULTS AND DISCUSSION}

Phytochemical investigation of the acetone extract of $C$. rotunda rhizomes using successive various chromatography techniques resulted in the isolation and elucidation of two flavanones, i.e. pinocembrin (1) and pinostrobin (2) (Fig.-1). Pinocembrin (1) was obtained as a yellow powder with a melting point of $189-190^{\circ} \mathrm{C}$ while pinostrobin (2) was isolated as a colorless-white powder with a melting point of 99$101^{\circ} \mathrm{C}$. FTIR spectra was used to identify the functional groups on both isolated compounds including O$\mathrm{H}\left(3400 \mathrm{~cm}^{-1}\right), \mathrm{C}-\mathrm{H} \mathrm{sp}{ }^{2}\left(3060 \mathrm{~cm}^{-1}\right), \mathrm{C}-\mathrm{H} \mathrm{sp}{ }^{3}\left(2970,2910 \mathrm{~cm}^{-1}\right), \mathrm{C}=\mathrm{O}\left(1630 \mathrm{~cm}^{-1}\right), \mathrm{C}=\mathrm{C}$ aromatic $(1480-$ $\left.1620 \mathrm{~cm}^{-1}\right)$, and C-O-C $\left(1150-1250 \mathrm{~cm}^{-1}\right)$.

Flavanone skeleton of two isolated compounds was identified by proton signal from ${ }^{1} \mathrm{H}$ NMR analysis at $5.42(d d, J=3.1,13.0 \mathrm{~Hz}), 2.83(d d, J=3.1,17.1 \mathrm{~Hz})$, and $3.10 \mathrm{ppm}(d d, J=13.0,17.1 \mathrm{~Hz})$ representative for ABX system in flavanones ${ }^{21}$. The strong intramolecular hydrogen-bonded appeared in both isolated compounds at a proton signal of $12.0 \mathrm{ppm}(s)$. A pair of doublets multiplicity $(J=2.0 \mathrm{~Hz}) \mathrm{in}$ the aromatic region at a chemical shift of $6.0 \mathrm{ppm}$ assigned for proton in ring A indicated tetrasubstituted benzene with three oxy-aryl carbon atoms from ${ }^{13} \mathrm{C}$ NMR data. Moreover, the presence of five protons 
RASĀYAN J. Chem.

Vol. 13 | No. 1 |322 - 326| January - March | 2020

aromatic at chemical shifts of 7.29-7.45 ppm allocated for phenyl group in ring B which correspond to monosubstituted benzene. The selected HMBC correlation for both isolated compounds was shown in Fig.-2.

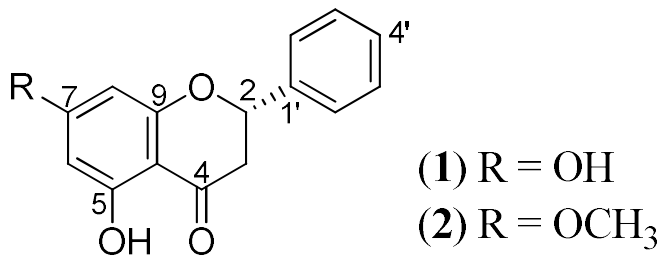

Fig.-1: Chemical Structure of Compounds 1-2

(a)

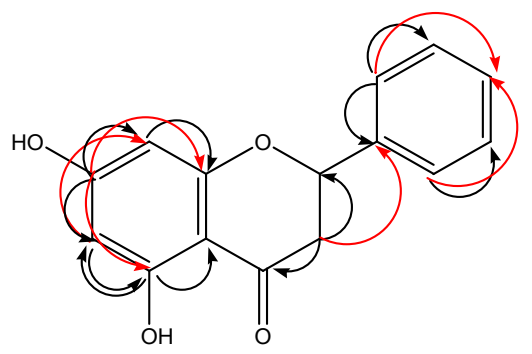

(b)

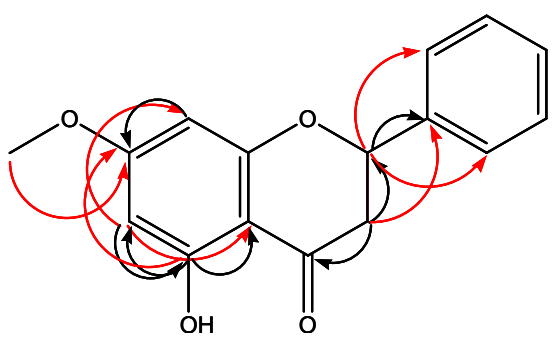

Fig.-2: Selected HMBC Correlation of Compounds (a) 1 and (b) 2

Table-1: ${ }^{1} \mathrm{H}$ NMR $(500 \mathrm{MHz})$ and ${ }^{13} \mathrm{C}$ NMR $(125 \mathrm{MHz})$ Data for Compounds 1-2 $\left(\mathrm{CDCl}_{3}\right)$

\begin{tabular}{|c|c|c|c|c|}
\hline \multirow{2}{*}{$\mathrm{C}$} & 1 & & 2 & \\
\hline & $\delta_{\mathrm{H}}$ & $\delta_{\mathrm{C}}$ & $\delta_{\mathrm{H}}$ & $\delta_{\mathrm{C}}$ \\
\hline 2 & $5.42(1 \mathrm{H}, d d, 3.1,13.0 \mathrm{~Hz})$ & 79.4 & $5.42(1 \mathrm{H}, d d, 3.1,13.0 \mathrm{~Hz})$ & 79.4 \\
\hline 3 & $\begin{array}{c}2.83\left(1 \mathrm{H}_{\mathrm{eq}}, d d, 3.1,17.1 \mathrm{~Hz}\right) \\
3.10\left(1 \mathrm{H}_{\mathrm{ax}}, d d, 13.0,17.1 \mathrm{~Hz}\right)\end{array}$ & 43.5 & $\begin{array}{c}2.83\left(1 \mathrm{H}_{\mathrm{eq}}, d d, 3.1,17.1 \mathrm{~Hz}\right) \\
3.10\left(1 \mathrm{H}_{\mathrm{ax}}, d d, 13.0,17.1 \mathrm{~Hz}\right)\end{array}$ & 43.5 \\
\hline 4 & - & 195.9 & - & 195.9 \\
\hline 5 & - & 164.5 & - & 164.3 \\
\hline 6 & $6.0(1 \mathrm{H}, d, 2.0 \mathrm{~Hz})$ & 96.9 & $6.07(1 \mathrm{H}, d, 2.0 \mathrm{~Hz})$ & 95.3 \\
\hline 7 & - & 163.3 & - & 162.9 \\
\hline 8 & $6.0(1 \mathrm{H}, d, 2.0 \mathrm{~Hz})$ & 95.7 & $6.09(1 \mathrm{H}, d, 2.0 \mathrm{~Hz})$ & 94.4 \\
\hline 9 & - & 103.3 & - & 103.3 \\
\hline 10 & - & 165.0 & - & 165.0 \\
\hline $1^{\prime}$ & - & 138.5 & - & 138.5 \\
\hline $2^{\prime} \& 6$ & $7.29(2 \mathrm{H}, m)$ & 126.3 & $7.29(2 \mathrm{H}, m)$ & 126.3 \\
\hline $3 ’ \& 5$ & $7.43(2 \mathrm{H}, m)$ & 129.0 & $7.43(2 \mathrm{H}, m)$ & 129.0 \\
\hline 4' & $7.45(1 \mathrm{H}, m)$ & 129.0 & $7.45(1 \mathrm{H}, m)$ & 129.0 \\
\hline $5-\mathrm{OH}$ & $12.03(1 \mathrm{H}, s)$ & - & $12.02(1 \mathrm{H}, s)$ & - \\
\hline $7-\mathrm{OCH}_{3}$ & - & - & $3.81(3 \mathrm{H}, s)$ & 55.8 \\
\hline
\end{tabular}

According to FTIR and NMR spectra data, there was no doubt that two isolated compounds were identified as pinocembrin (1) and pinostrobin (2) with the molecular formula of $\mathrm{C}_{15} \mathrm{H}_{12} \mathrm{O}_{4}$ and $\mathrm{C}_{16} \mathrm{H}_{14} \mathrm{O}_{4}$, respectively. Both of isolated compounds had been identified previously from the rhizomes of $C$. rotunda cultivated in Surabaya ${ }^{21}$ and Yogyakarta, Indonesia ${ }^{22}$. These findings and literature studies revealed the first study which reported that pinostrobin (2) is the major flavanone in C. rotunda ${ }^{23}$.

Based on the antibacterial assay, all of the isolated compounds did not show antibacterial activities toward both of bacteria tests. It can be assumed because of little concentration of the isolated compounds during the antibacterial assay since both of isolated compounds are slightly nonpolar compounds having low solubility in water. There are four major factors affecting the antibacterial activity results including type, concentration, and diffusion property of the compounds, as well as the bacteria type ${ }^{24}$. Recent 


\section{RASĀYAN J. Chem.}

Vol. 13 | No. 1 |322 - 326| January - March | 2020

studies reported that pinocembrin (1) exhibited antibacterial activity toward Escherichia coli with an inhibition concentration of $250 \mu \mathrm{g} / \mathrm{mL}^{22}$. Moreover, pinostrobin (2) showed wide-range antibacterial activities towards E. coli, Bacillus subtilis, Shigella dysenteriae, and Heliobacter pylori with MIC values of $37.5,37.5,75$, and $125 \mu \mathrm{g} / \mathrm{mL}$, respectively ${ }^{25}$. According to antibacterial activity studies, both isolated compounds displayed antibacterial activities in a limited number of bacteria which many scholars have not yet been explored in detail with other bacteria. Therefore, these findings demonstrated that two flavanones are inactive toward S. aureus and Pseudomonas sp.

\section{CONCLUSION}

In this study, we report further experimental scientific to isolate secondary metabolites from C. rotunda rhizomes and examine for antibacterial activities. Phytochemical analysis of the acetone extract of $C$. rotunda rhizomes led to the isolation of two flavanones, namely pinocembrin (1) and pinostrobin (2). However, both isolated flavanones did not show antibacterial activities toward S. aureus and Pseudomonas sp. Further studies will need to be conducted to assay in other bacteria.

\section{ACKNOWLEDGMENT}

The Authors thank the Department of Chemistry, Institut Pertanian Bogor, 2018 research grant for funding this research.

\section{REFERENCES}

1. C. Gyles, The Canadian Veterinary Journal, 52(8), 817(2011).

2. D. E. Djeussi, J. A. K. Noumedem, J. A. Seukep, A. G. Fankam, I. K. Voukeng, S. B. Tankeo, A. H. L. Nkuete and V. Kuete, BMC Complementary and Alternative Medicine, 13, 164(2013), DOI: 10.1186/1472-6882-13-164

3. P. Wikaningtyas and E. Y. Sukandar, Asian Pacific Journal Tropical Biomedicine, 6(1), 16(2016), DOI: $10.1016 / j$.apjtb.2015.08.003

4. P. Sugita, N. Octaviana, T. Wukirsari and D. U. C. Rahayu. Journal of Pharmacy Research, 12(3), 293(2018).

5. D. U. C. Rahayu, S. N. 'Adilah and P. Sugita. European Journal of Pharmaceutical and Medical Research, 5(3), 582(2018).

6. D. U. C. Rahayu, Hartono and P. Sugita. Rasayan Journal of Chemistry, 11(2), 762(2018), DOI: 10.7324/RJC.2018.1122076

7. P. Sugita, S. O. Firdaus, A. Ilmiawati and D. U. C. Rahayu. Journal of Pharmacy Research, 10(6), 68(2018).

8. Purwantiningsih, Hartono, S. O. Firdaus, Kurniawanti, D. U. C. Rahayu, L. Nurhayati, A. Ilmiawati and T. Wukirsari. Drug Invent. Today, 11(2), 386(2019).

9. D. U. C. Rahayu, D. Nurfadhilah and P. Sugita. International Journal of Pharmaceutical Sciences and Research, 10(7), 3354(2019), DOI:10.13040/IJPSR.0975-8232.10(7).3354-58

10. A. Chahyadi, R. Hartati, K. R. Wirasutisna and Elfahmi. Procedia Chem. 13, 13(2014), DOI: 10.1016/j.proche.2014.12.003

11. T. Eng-Chong, L. Yean-Kee, C. Chin-Fei, H. Choon-Han, W. Sher-Ming, C. T. Li-Ping, F. GenTeck, N. Khalid, N. A. Rahman, S. A. Karsani, S. Othman, R. Othman and R. Yusof, Evidence-Based Complementary and Alternative, 2012, 1(2012), DOI: 10.1155/2012/473637

12. T-Y. Wang, Q. Li and K-S. Bi. Asian Journal of Pharmaceutical Sciences 13(1), 12(2018), DOI: 10.1016/j.ajps.2017.08.004

13. D. Maaliki, A. A. Shaito, G. Pintus, A. El-Yazbi and A. H. Eid. Current Opinion in Pharmacology, 45, 57(2019), DOI:10.1016/j.coph.2019.04.014

14. C. Faggio, A. Sureda, S. Morabito, A. Sanches-Silva, A. Mocan, S. F. Nabavi and S. M. Nabavi, European Journal of Pharmacology, 807, 91(2017), DOI: 10.1016/j.coph.2019.04.014

15. K. R. R. Rengasamy, H. Khan, S. Gowrishankar, R. J. L. Lagoa, F. M. Mahomoodally, Z. Khan, S. Suroowan, D. Tewari, G. Zengin, S. T. S. Hassan and S. K. Pandian. Pharmacology \& Therapeutics, 194, 107(2019), DOI: $10.1016 /$ j.pharmthera.2018.09.009 
RASĀYAN J. Chem.

Vol. 13 | No. 1 |322 - 326| January - March | 2020

16. H. Khan, S. Perviz, A. Sureda, S. M. Nabavi and S. Tejada. Food and Chemical Toxicology, 119, 176(2018), DOI: $10.1016 /$ j.fct.2018.04.052

17. L. Jalili-Baleh, E. Babaei, S. Abdpour, S.N.A.Bukhari, A.Foroumadi, A.Ramazani, M. Sharifzadeh, M.Abdollahi, M. Khoobi, European Journal of Medicinal Chemistry, 152, 570(2018), DOI: 10.1016/j.ejmech.2018.05.004

18. A. Ghorbani, Biomedicine \& Pharmacotherap, 96, 305(2017), DOI: 10.1016/j.biopha.2017.10.001

19. J. R. Frandsen and P. Narayasanamy. Redox Biology, 14, 465(2018), DOI: 10.1016/j.redox.2017

20. W.W.Davis, T.R.Stout, Applied Microbiology, 22(4), 659(1971)

21. M. Tanjung, T. S. Tjahjandarie and M. H. Sentosa, Asian Pacific Journal Tropical Disease, 3(5), 401(2013), DOI: 10.1016/S2222-1808(13)60091-2

22. S. Atun, S. Handayani and A. Rakhmawati, Pharmacognocy Journal, 10(3), 513(2018), DOI: 0.5530/pj.2018.3.84

23. T. Jaipetch, S. Kanghae, O. Pancharoen, V.A.Patrick, V.Reutrakul, P.Tuntiwachwuttikul, A.H.White, Australian Journal of Chemistry, 35, 351(1982), DOI: 10.1071/CH9820351

24. Y. Lestari, P. Ardiningsih and Nurlina, Jurnal Kimia Khatulistiwa, 5(4), 1(2016).

25. S. M. Dewi, D. Mujahidin and Y. M. Syah, in Seminar Nasional Kimia dan Pendidikan Kimia VI, Jun 21 (2014), Surakarta, Indonesia.

[RJC-5484/2019] 